\title{
Analyzing Political Marketing in Indonesia: A Palm Oil Digital Campaign Case Study
}

\author{
Fajrina Khairiza ${ }^{1}$, Bevaola Kusumasari ${ }^{2 *}$ \\ 1 Department of Public Policy and Management, Faculty of Social and Political Sciences; \\ fajrina.k@mail.ugm.ac.id \\ 2 Department of Public Policy and Management, Faculty of Social and Political Sciences; \\ bevaola@ugm.ac.id \\ * Correspondence author: bevaola@ugm.ac.id
}

\begin{abstract}
Social media in political marketing is an emerging area of research. This study explains how social networks are constructed in a digital campaign, identifying key actors, and messages involved in modern political marketing. A hotly contested palm oil campaign in Indonesia serves as a case study to analyze and visualize the messaging content found in digital campaigns. Social Network Analysis (SNA) was used to map the social network sites in Twitter and to track social interaction patterns in the \#SawitBaik campaign. The results confirmed that state institutions, non-governmental institutions, news media, and individuals were key actors in the digital campaign. The actors' roles varied from providing information and supporting palm oil activities to criticizing palm oil activities and promoting campaign events. Most tweets were critical of the government, serving as brand advocacy. The \#SawitBaik campaign is also an example of political marketing used by a government in order to influence its citizens. In this case, the goal was to shape and win public support by legitimizing palm oil activities in Indonesia.
\end{abstract}

Keywords: political marketing; digital campaign; social network analysis; palm oil

\section{Introduction}

The palm oil trade is debated widely among stakeholders around the world. Global demand for palm oil has increased significantly in recent decades. According to Palm Oil Analytics (2017), three regions generate the greatest demand. India accounts for more than $30 \%$ of total global imports, followed by the European Union and China. The rapid growth in world palm oil demand in the last decade is reflected in total palm oil supply growth in producing countries, particularly in Indonesia, with global palm oil production increasing every year (Austin et al., 2017). Palm oil is now one of the most traded agricultural commodities in the world.

Despite the success of the palm oil industry, critics have challenged palm oil production and sought to ban palm oil imports (Suwarno, 2019). The Southeast Asian palm oil industry has attracted the attention of international, non-governmental organizations (NGOs). These environmental groups worry about the sustainability of the area's production processes, which have adversely affected the ecological system (Klarin, 2018). In responding to such negative claims, the Ministry of Communication and Information, together with the Palm Oil Plantation Fund Management Agency Indonesia and the Coordinating Ministry for Economic Affairs Indonesia, launched a political marketing campaign. It sought to provide palm oil updates using social media platforms and began in September, 2019 (Negara, 2019). The campaign used \#SawitBaik on Twitter as a governmental effort to inform and educate the public about palm oil as well as to build online awareness and diplomatic goodwill with the world community. The hashtag was designed to influence others, a symbol for a movement that wanted individuals to become part of a much larger movement (Bruns et al., 2011). Twitter was chosen because this social media platform is often used for online advocacy efforts due to its instant information distribution (Burger, 2015).

An emerging body of literature has explored the use of social media in political marketing (Hanska, et al., 2018; Barisione et al., 2017; Saxton et al., 2015). However, most of these studies examine only the prevalence of social media, or whether organizations use social media for their campaigns; previous studies barely explained social networks in political marketing. There is a 
striking need for research about who are the actors and what their role is behind political marketing and how social networks can be constructed for a digital campaign. In the background, this study emphasizes the advancement of technology in political marketing; therefore, this research will be relevant to many actors from the level of stakeholders, as is the case of the palm oil campaign in Indonesia, \#SawitBaik.

Our analysis of the palm oil campaign in Indonesia is due in part to the rapid development of this industry, which has attracted wide-spread attention from various parties questioning its sustainability in the industrial process. This research aims to highlight the actors' involvement and role behind a digital campaign; to analyze the message content of digital campaigns; and to visualize social network analysis (SNA) using the case of the palm oil campaign in Indonesia. Lastly, the paper has four parts. First, it reviews the previous relevant academic literature for political marketing and digital campaigns. Second, the research methodology and data collection analysis are discussed. Third, the results are analyzed. And fourth, we offer conclusions followed by potential future research.

\section{Literatur Review}

\subsection{Political marketing}

Political marketing as a discipline derived from the core of marketing literature. It is designed to inform and influence political action (Lock and Harris, 1996). Maarek (1995) believes that political marketing is an important process in political campaigns that is related to the constituent. Marian (2013) states that political marketing can be viewed as a technique aimed at promoting electors' suitability to potential voters in order to distinguish themselves from the competition in election with minimum resources.

Political marketing assists in communicating the message of the campaign to the target audience. The key components of political marketing are image, branding, and how social media affects the effectiveness of the various components of the program offered (Lees-Marshment, 2011; Thejllmoller,2013). The aims of political marketing are to communicate the vision and mission of the candidate or institution, to persuade the citizens, and to maintain a good image (Zelenak, L.A, 2013). Political marketing also developed in order to bridge the gap between what the citizen expects from government and what government delivers to the citizen. Political marketing requires resources such as time, money, and information to be utilized and advocated (Smith \& French, 2009). Time is a crucial resource because it is used to target the audience with precision and turn citizens into campaign advocates. Political marketing requires a number of programs to support electoral awareness. These include focus group discussions, polling, and public relations. They all help voters or target groups make a correct decision and impact directly the level of political engagement (LeesMarshment, 2011).

Studies about political marketing often discuss the communication processes between voters and political parties in the election (Wring, 1997; Lock and Harris, 1996; Kavanagh, 1995; McNair, 1996; Newman, 1994). In recent years, political marketing as a campaign strategy has entered a new era, filled with social media platforms, drastically changing demographics, social networking, and increasingly segmented audiences. However, few have devoted much attention to how governments use political marketing to influence citizens in order to retain public support for chosen programs or policies. This study provides a link between the campaign, politics, and social media used by institutions in order to have greater resonance for their causes. Our research provides evidence that political marketing should be viewed in context, with various issues and actors involved who interact with governmental objectives in the political discourse.

Through the help of technology, political marketing has changed how people connect and share information. Electronic activism and viral marketing now use more targeted messages through 
online petitions, blogs, social media sites, and other platforms of mass media communication. They have further reduced the need for activists to get out in the streets or to engage in expensive media campaigns to spread their message (Saxton, et al., 2015). Many online campaigns are successful in directly influencing policy, public response, and constituencies. Social media-based advocacy ultimately involves a focus on organization-audience communication (Casey, 2011).

To conclude, political marketing can be defined as technologically advanced marketing that uses an interconnected platform to share digital information without reducing the value of voters or target groups. Hence, political marketing is effective because it generates greater public participation in campaigns compared to traditional marketing tactics. Political marketing is one of the core strengths of governance because it can create enduring change, invite citizen involvement in public policy, and address long-term social issues.

\subsection{The Digital Campaign}

Information and communications technologies (ICTs) have dramatically changed the landscape of citizen commitment by promoting new products and issues. Through ICTs, users receive linked, open access to knowledge, which offers a wealth of new possibilities (Johansson \& Scaramuzzino, 2019). ICT platform development for political marketing has received attention from many groups, both academics and practitioners (Goldkind \& McNutt, 2019). ICT devices are increasingly available, including those linked to mobile and Internet networks. As political marketing moves to the digital sphere, effective public communications and discussion must use specific messages (Munoz \& Gracia, 2016). However, the accessibility of new media provided by digital, interconnecting technologies is a challenge both for public and business sectors.

Digital campaigning is defined as a space for the action of liberation to express problems in one part of the policy-making process that affects public policies, social attitudes, or political processes (Gou \& Saxton, 2012). A digital campaign represents the stresses of the community, organizations, or institutions as perceived by the authorized party. As one of the core influences in the policymaking process, political marketing contains content values that share informational knowledge for the audience from a variety of aspects, such as business, education and the sciences (Happer \& Philo, 2013,).

Before the development of ICTs, digital campaigns were hampered by limited media platforms to engage the audience. Digital networks and connected content have created a greater level of democratic participation, civic engagement, and social activism. Digital campaigns have also been used as a publication platform for practitioners, academics, and organizations both in developed and developing countries. For instance, World Wildlife Funds, as the leading NGO in wildlife conservation, uses digital media platforms to advocate endangered animal habitats to support their programs through crowdfunding (Zheng \& Liu, 2017). In addition, digital campaigns are often used as a forum for political information and political discussion and how groups gain political influence through social media as the study was conducted by Johansson \& Scaramuzzino (2019) in the analysis of worker's right in Sweden.

The development of digital technologies and new media platforms has become spurred for the researcher's activities. Research conducted by The London School of Economics (Hanska, et al., 2018) explained how the emergence of online advocacy and public discussion through social media tweetsphere across European countries, can be rapidly peaked in a very short time. Barisione et al., (2017) analyzed how the response, discussions and public opinion on tweetsphere with the hashtag of \#RefugeesWelcome can be gathered and classified into digital movement of opinion (DMO) theory. Another example is a study by Saxton et al., (2015) measures the frequency pattern of online advocacy through social media tweetshpere on United State of America National Health Council $(\mathrm{NHC})$ with the board of directors member. By looking at these examples, the study of social media 
and online advocacy is certainly becoming an important consideration to understand public and organizational behavior.

We note that the use of social media applications is increasing rapidly in line with technological and social developments. This medium has become a very important modern form of political communication, along with the fact that social media has become popular and gained popularity with the possibilities it offers for representatives, organizations and most importantly ordinary citizens (Kurt \& Karaduman, 2012). The increasing popularity of actor's analysis in social media reflects an increasing recognition of the extent to which actors can influence the decision-making processes (Duram \& Brown, 1999). Actors analysis is done as a method to analyze the actors involved in some activity (Bryson, 2004). Online tools and social media offer new possibilities for educating people and stakeholder organizations, defining common interests, voicing and exchanging opinions and requests, planning and managing initiatives (Hoffman \& Lutz, 2014). With the various kind of actors that actively engage and participate in social media such as Twitter, it is certainly needed to be observed the classification of actors in social media through the use of their social media.

Previous studies have discovered the classification of actors in social media in accordance with their profile use. According to Vassiliadis et al., (2015), there are several classification of actors in social media; state institution which consist of official governmental social media accounts, nongovernmental institution which is an independent institution that raises a specific issues for their vision and mission (Lewis, 2010), news mass media, which means media and informational company or organization social media account, and the last is individual that links to an individual's personal account of social media. These classifications were applied in the research conducted in several social media account such as Twitter, Facebook and also can measure actors involved in social media participation.

Vassiliadis et al., (2015) explained the four classifications of actors in social media have their own role in social media which also linked to their updates toward an issue. As one of the actors who has a strong power in policy-making and also the sustainability of state affairs (Robinson, 2006), State institution actors in social media were dominantly giving the information or support regarding related issues that emerged nationally or correlated with the specific governmental institution. For some examples, are the national police official account shares the information on their social media about current terrorism attack. Non-Governmental Institutions' role in social media also shares information that related to their purposes of the organizations, it can be criticism against some cases, advocacy, and also knowledge. News mass media actors in social media have the biggest influence compared to other actors due to the rapid information and shares, these actors share various kind of news from updated issue, socio-economy to daily life (Friedrichsen, 2013). Individual actors' role in social media shares their personal thoughts regarding particular issues or posts. To conclude, social media actors are used to identifying the background of emerging issues or social media updates in accordance with their user profile. Previous studies have discovered various types of actors involved in social media to make the classification of actors in social media. With the designation of the social media actor, it opens up a large opportunity to deepen the examination of actors and their position in social media. Through a list of actors in social media on some topics or updates, it also broadens such research to look at their influence on other related actors.

\section{3 \#SawitBaik as a Palm Oil Digital Campaign}

The Indonesian government conducted a \#SawitBaik campaign on social media with the aim of providing better information about Indonesian palm oil. This campaign was supported by the Palm Oil Plantation Fund Management Agency (BPBD), the Coordinating Ministry for the Economy, and the Ministry of Communication and Information. The movement aims to fight the negative perception of palm oil. In the areas of Sumatra and Kalimantan, the industry has been accused of 
producing large-scale forest and land fires. The production process creates a dense haziness from trees and land fires, affecting the public's safety and activities.

The \#SawitBaik Movement seeks to provide a more positive image about palm oil, which is the largest foreign exchange earner for Indonesia and a large employer of labor. Environmental activists from Greenpeace emphasize that the \#SawitBaik campaign was not appropriate because the forest fires were mostly caused by palm oil and pulp and paper entrepreneurs. In a study conducted by the Center for International Forestry Research, it was confirmed that many palm oil entrepreneurs chose to burn palm oil land because it required low costs, less time consuming and could also make fertilizers and eliminate diseases such as fungus on palm oils. land is farmers, entrepreneurs, and large corporations. Claims that palm oil is a large foreign exchange owner are questioned as losses are higher than earnings. The losses generated are not only economic but also social consequences such as impeded educational activity. The \#SawitBaik campaign is seen as not being able to voice a variety of violations committed by these actors such as non-transparent licensing, as well as the coercion of planting palm oil on peatlands. The \#SawitBaik campaign actually emphasizes that palm oil can prosper the people

\section{Research Methods}

\subsection{Case and Methods Selection}

This study was carried out by using two approaches: SNA and qualitative content analysis. The researchers chose a multi-method analysis approach, which measure different components quantitatively and deepen the validity of the findings data with the literacy study approach, thus increasing the reliability of the results (Erzberger \& Kelle, 2003). SNA have been used to advance social and behavioral science since the mid-1930s (Carrington et al., 2005). SNA can be defined as a specific application of graph theory in which points and their social relations represent individual and other social actors (Scott \& Carrington, 2011). SNA emphasizes the relationship between actors as the central focus, which consists of set nodes or actors, along with a set of ties of a single type that connect the nodes (Borgatti \& Ofem, 2010). The nodes can be persons, teams, departments, organizations, industries, or any kind of object that is capable of having some kind of interaction with another entity. Ties can be a variety of types, such as friendships between individuals, communication patterns, or exchange information between industries (Borgatti \& Ofem, 2010). SNA links between nodes and are linked from paths that provide a mechanism so that nodes may indirectly affect others (Carrington et al., 2005).

Three types of central network interventions are suggested for the SNA framework, which define the advantageous role of opinion leaders: degree, betweenness, and closeness (Freeman, 1979; Liu etcoll., 2010). The central degree quantifies the number of connections from and to a network person. Persons with a high degree of centrality are more likely to become leaders in the opinion because increased social ties lead to greater access to and dissemination of information (Liu et al., 2010). Betweenness centrality calculates the rate at which the individual node is situated on the shortest path to reach the other nodes in the network, with high-focused individuals being the network's bridge. (Dublin, 1979). Closeness centrality calculates the average distance between the actual node and all other nodes on the network. Entities with a higher centrality of proximity require relatively fewer measures to access all other entities in the network and thus can potentially move information faster (Freeman, 1979, Liu et al., 2010). The explanation shows how SNA can work based on the measurement of the central network that occurs in a case. In addition, using a specific case will help the researcher to investigate a real-life phenomenon in a comprehensive way (Yin, 2009). SNA is now widely used in the field of online research, particularly in social media such as Twitter (Bruns, 2012; Calvo et al., 2016; Rogers, 2013). In our current research, SNA can map social network sites (SNSs) like Twitter and be used as a tool to track the pattern of social interaction. 


\subsection{Data Collection}

This study analyzed the hashtag \#SawitBaik as the main source of observable data. The timeframe used by the authors in analyzing this campaign was from September 3rd, 2019 to November $1^{\text {st }}, 2019$. The results obtained in the search for tweets from the Twint application were 9,628 tweets. Data collection conducted in this research was carried out through Drone Emprit Academy (DEA). DEA was developed by Astramaya, a start-up company that focuses on ideata analysis. Astramaya analyzes conversations and news (both social media and mass media) using Kernels Media software. Kernels Media is a system that monitors and analyzes social media and online platforms based on Big Data technology (Suharso, 2019). The DEA platform was developed by Ismail Fahmi in 2009 in Amsterdam, the Netherlands under the name Media Kernels Netherlands. It allows researchers to gain insight and act based on data and analysis, which is managed and processed properly by a back-end computer and presented via a front-end dashboard. Additionally, data naturalization using the Openrefine application sorted the tweet components into a source for username and target as uploaded tweets. The data naturalization obtained was 14,779 tweets. The process was then moved to the Gephi application in order to see nodes in the source and target networking map. After obtaining data, the tweets were then categorized using Saxton et al (2015) social media usage that is described in Table 1.

Table 1. Social Media Usage Categories

\begin{tabular}{|c|c|c|}
\hline No. & Categories of Social Media Used & Description \\
\hline 1. & Criticizing the Government & $\begin{array}{l}\text { Tweets discussing sociopolitical implications and } \\
\text { responsibilities for the issue. }\end{array}$ \\
\hline 2. & Advocacy Branding & Tweets containing advocacy branding about events. \\
\hline 3. & Discussing Causes & Tweets discussing scientific causes about the issue. \\
\hline 4. & Community Engagement & $\begin{array}{l}\text { Tweets discussing community engagement and participation } \\
\text { through activities related to the issue. }\end{array}$ \\
\hline 5. & Knowledge Share & $\begin{array}{l}\text { Tweets discussing usability benefits, informational knowledge } \\
\text { regarding the event. }\end{array}$ \\
\hline
\end{tabular}

Source: (Saxton et al., 2015)

\subsection{Data Analysis}

We analyzed the data using the descriptive qualitative approach to provide a comprehensive description of the encounter that is easily understood. A qualitative description approach offers the possibility of gathering rich descriptions about a little-known phenomenon. During the process, the researchers sought to keep close to the data and events surrounding the experience from the point of view of the tweets (Sandelowski, 2000). We categorized tweets posts in a dataset based on actors' classification explained by Vassiliadis et al., (2015). The researchers sought to discover and understand the actors behind \#SawitBaik advocacy and also the role of those actors in \#SawitBaik advocacy.

After the classification of actors behind \#SawitBaik and its role, we then categorized the tweets into a dataset based on the categories used by Saxton et al., (2015) on Twitter messages in the case of \#AdvocatingForChange. In their category research, they categorized five message categories to define the content posts (Table 1). Furthermore, we provided SNA using the DEA platform to test the central network that is formed on the \#SawitBaik network. DEA uses the expertise of Artificial Intelligence and Natural Learning Process (NLP) so that it can present a SNA map of how the 
\#SawitBaik is spread, influential figures based on likes and retweets and words that often appear. DEA also provides research findings by using measurements described by Liu et al., (2010) that is based on degree, betweenness, and closeness in the given timeframe.

The aim of using SNA method is to show who is the central network that has opinion leaders that have the influence to other related issues on the topic. The first process determines the role of social media, such as Twitter, in a digital campaign and conducts SNA. The process uses the Gephi programming language application for text analysis. For an advanced search in the content message, this study uses the hashtag "\#," as this symbol is often used for digital campaigns or political marketing as their target issue. With the data that has been obtained from Twitter, the study conducted a network mapping that provides useful information about the users' influence on the digital campaign. Metadata, which was carried out from social media networks, reveal information about individual participation and their connections, which can be assessed by the number and nature of connection action (Smith, Rainie, Shneiderman, \& Himelboim, 2014). Mapping the relationships of the message regarding a certain issue allows the identification of users who are part of highly connected subnetworks or clusters (Himelboim, McCreery, \& Smith, 2013).

\section{Results and Discussion}

\subsection{Actors and their Involvements in the \#SawitBaik Digital Campaign}

As one of the forms of digital campaign activity that emphasizes community information toward the palm oil industry, the hashtag \#SawitBaik has attracted a lot of attention from various actors and also their perception toward the digital campaign. In this study, we conducted two different ways of collecting data to process the findings of the study, namely SNA and descriptive qualitative approach. The results show various kinds of actors behind \#SawitBaik as presented in Table 2 . In the process of the digital campaign activities, it was explained that it is required to have actions both contradictory and supportive toward an issue in order to form a consensus that becomes a part of the public policy process (Unsicker, 2012). Referring to Sabatier (2007) in the involvement of actors in policy advocacy process, each actor has an important involvement in the campaign issue, namely as one of the supporters of the program, raising awareness, disseminating news, and expressing opinions on issues raised in related advocacy. The data we obtained in the classification of actors shows that the actors behind \#SawitBaik digital campaign have their respective roles as it is explained in the involvement of actors in the process of policy advocacy by Sabatier (2007).

Table 2. List of actors on \#SawitBaik Digital Campaign

\begin{tabular}{cccc}
\hline State Institution & $\begin{array}{c}\text { Non-Governmental } \\
\text { Institution }\end{array}$ & News Mass Media & Individual \\
\hline @SawitBaikID & @PPKS_Medan & @antaranews & @ernestprakasa \\
@BPDP_Sawit & @greenpeaceid & @thejakartapost & @elisa_jkt \\
@PKKIKemlu & @walhinasional & @detikcom & @dandhy_laksono \\
@infosawit & @jaringanindmuda & @liputan6com & @ismailfahmi \\
@KementrianLHK & @orangutanfdn & @tirtoid & @okapi_blue \\
@IndonesiainPL & @wwf_id & @merdekadotcom & @miqfani \\
@kemkominfo & @EmeraldPalmOil & @republikaonline & @tweetspiring \\
@PerekonomianRI & @sulungresearch & @beritagarlD & @febrofirdaus \\
\hline
\end{tabular}

\subsubsection{The Involvement of State Institution}

To answer the question of the actor and its involvement in the digital campaign of \#SawitBaik, we classified the Twitter accounts by sorting them into four sections, namely: State Institution, NonGovernmental Institution, News Media, and Individual. The results found that the actors in the state 
institution came from different sectors of governmental parties such as "BPDP_Sawit," as a government fostered institution in managing palm oil funds, "IndonesiainPL" Indonesian Embassy in Poland, to the account of the directorate of trade, commodities and intellectual property "PKKIK_Kemlu." Posts made in response to \#SawitBaik digital campaign on each account are also different, such as the "SawitBaikID" account as a government platform in \#SawitBaik campaign, dominating posts about palm oil education in daily life. The "PerekonomianRI" account provides information on the Indonesian palm oil trade update, while the "kemkominfo" account posted their support on \#SawitBaik advocacy and also updates regarding activities related to \#SawitBaik events.

Actors included in the category of state institutions as explained by Robinson (2006) have their respective roles in \#SawitBaik digital campaign, such as the Ministry of Communication and Information which hold "kemkominfo" Twitter account, in collaboration with the Coordinating Ministry of Economic Affairs which has "PerekonomianRI" Twitter account, the Ministry of Environment which has "KementrianLHK" Twitter account, Palm Oil Plantation Fund Management Agency which has "BPDP_Sawit" Twitter account are internal actors that release and supports \#SawitBaik campaign programs and also the fostered platform related to campaign on social media. The support they provide is the allocation of programs, funds, and infrastructure in creating the \#SawitBaik campaign social media platform (Negara, 2019). As the main actor in the \#SawitBaik digital campaign, under the management of various ministries, namely "SawitBaikID" and "infosawit" Twitter account, they have involvement as an extension of internal actors by providing awareness and educational knowledge related to the campaign. Meanwhile, the involvement of other government institutions such as the Twitter account of the Directorate of Trade, Commodity and Intellectual Property Ministry of Foreign Affairs, and the Indonesian Embassy of Poland provides information to the public regarding developments in the \#SawitBaik activities.

\subsubsection{The Involvement of Non-Governmental Institution}

As defined, a non-governmental institution is an independent organization that poses specific issues for its vision and mission (Lewis, 2010). We obtained the data in the category of the nongovernmental institution, which involved various kinds of background on the actors. Our findings reveal that most of the actors involved in \#SawitBaik digital campaign are institutions with a nature conservation background such as "greenpeaceid," as one of the organizations engaged in international-scale environmental campaigns. Other interesting findings: There are several research institutions that also become a part of \#SawitBaik advocacy actor, such as "PPKS_Medan," the official account of Indonesian palm oil research institute and "sulungresearch" a research center under the Indonesian palm oil company, PT. Sawit Sumbermas Sarana. Posts made by each account are different; for some, examples posts published by organizations with environmental conservation backgrounds such as "greenpeaceid" expressed criticism toward \#SawitBaik advocacy, which was judged to be uncorrelated on the field facts. Meanwhile, an account with a research institution background posted such as "PPKS_Medan" and "sulungresearch" tweets underlie community education about the development of the palm oil industry.

As an institution that has a focus on issues as their vision and mission (Lewis, 2010), nongovernmental institution actors have involvement as external actors who express their expressions and opinions on the issues they are concerned about. Based on Sabatier (2007) explanation in the involvement of actors, the non-governmental institution in their involvement is more expressing their standing points regarding the advocacy in the form of opinions, as done by external actors such as Greenpeace, Walhi Indonesia,, Orangutan foundation, and WWF. This actor has a big influence because the network has been formed on a large-scale both nationally and internationally. Meanwhile, the role of other external actors in non-governmental institutions, such as research center bodies, acts as an actor who spreads awareness to the public about \#SawitBaik campaign based on education. Therefore, by looking at this analysis it is proven that the involvement of non- 
governmental institution actors is varied and applied the concept of the role of actors in the policy advocacy process.

\subsubsection{The Involvement of News Mass Media}

As one of the platforms that have a great influence on society in the context of information sharing, news media are often used as a source of information for the community as a reference for the latest news (Cook, 2010). Based on the data we obtained in the news mass media category, shows that there are numbers of news media accounts that are actors behind \#SawitBaik with a variety of English-based media backgrounds such as "thejakartapost," a news media platform that utilizes data such as "beritagarID," online news media such as "detikcom" and "tirtoid." Each of these accounts is involved in providing various information and perspectives on \#SawitBaik campaign. Examples of variations in information provision and perspective toward \#SawitBaik are "thejakartapost" and "tirtoid" accounts writing critics of \#SawitBaik advocacy when forest and land fires occurred at that time on their articles. In contrast to articles written by "antaranews" and "merdekadotcom" which explain the release of \#SawitBaik campaign on social media platforms supported by the government. Meanwhile, "beritagarID" provides information on \#SawitBaik advocacy and education understanding about palm oil based on the data they have obtained. By seeing this result, we can see that there are different perspectives in each news media that can also affect the readers in responding \#SawitBaik advocacy. As one source of information read by all audiences (Cook, 2010), the mass media has an important role in \#SawitBaik campaign, namely as an external actor who disseminates news to the public. News mass media has become one of the most influential actors due to their large network and the rapid spread of information to the public. This shows that actors, which included the category of news mass media, are involved in the actor's policy advocacy process as the disseminating news.

\subsubsection{The Involvement of Individual}

Social media such as Twitter can be a medium for the community or individual to express their aspirations and opinions on a topic being discussed (Hanska et al., 2018). As can be seen in Table 2 above, there are eight personal Twitter accounts and with different backgrounds. An example is "ernestprakasa" which is a public figure and also a politician, "ismailfahmi" a researcher and founder of DEA, which is a platform that functions to monitor and analyze social media and online platforms based on Big Data technology, a journalist "febrofirdaus." This actor has a involvement in conveying aspirations and opinions on \#SawitBaik advocacy from various perspectives. For example, a tweet posted by the "tweetspiring" account is information about \#SawitBaik's ongoing activities. "Miqfani" account posted a video related to the palm oil industry and its impact on the environment, while the accounts "ernestprakasa," "dandy_laksono" and "ismailfahmi" posted tweets of government criticism of \#SawitBaik advocacy. The last is the involvement of external actors in \#SawitBaik advocacy, which has a big influence on the opinions expressed, namely Individual. The role of most of the actors included in the Individual category in \#SawitBaik advocacy is to express opinions about advocacy or in Sabatier (2007) explanation regarding indicators of the involvement of actors in the policy advocacy process is public expression. This can be evidenced by the response of each individual to \#SawitBaik campaign such as "ernestprakasa" politicians who express criticism of the hashtag \#SawitBaik. However, it is not always the actors belonging to the Individual category expressing personal opinions; some of them also share awareness and education about \#SawitBaik campaign to the public. 


\subsection{Types of Messages}

In order to see the message content and also the response from the community related to \#Sawitbaik campaign, we conducted a content analysis on messages from Twitter who used the \#SawitBaik hashtag, we use a basic classification scheme for 9,629 tweets into five categories from the research of Saxton et al., (2015). Table 3 shows the classification results of the total tweets in total. Of the five categories of message types namely: Criticizing the Government, Advocacy Branding, Discussing Causes, Community Engagement, and Knowledge Share, the "Criticizing the Government" category, "Discussing Causes" and "Advocacy Branding" are the three most frequently uploaded messages in all related tweets of the \#SawitBaik campaign.

In accordance with our findings in classifying messages in tweets using the hashtag \#SawitBaik, the category of criticizing the government places first position on the contents of messages relating to \#SawitBaik campaign. With a percentage of $39.8 \%$ of the total tweets, this suggests that \#SawitBaik's campaign has drawn criticism from the public response. This certainly affects the discussion about \#SawitBaik's campaign with the emergence of other issues. According to RoseAckerman (2006), criticism of the government is an action taken by the community to increase government awareness to pay attention to every aspect of their work. Next, is the discussing causes category, which places second from the total number of tweet posts. This shows that there is a discussion about the impact that can occur from the topic being raised in the form of public concern for the palm oil industry and this campaign.

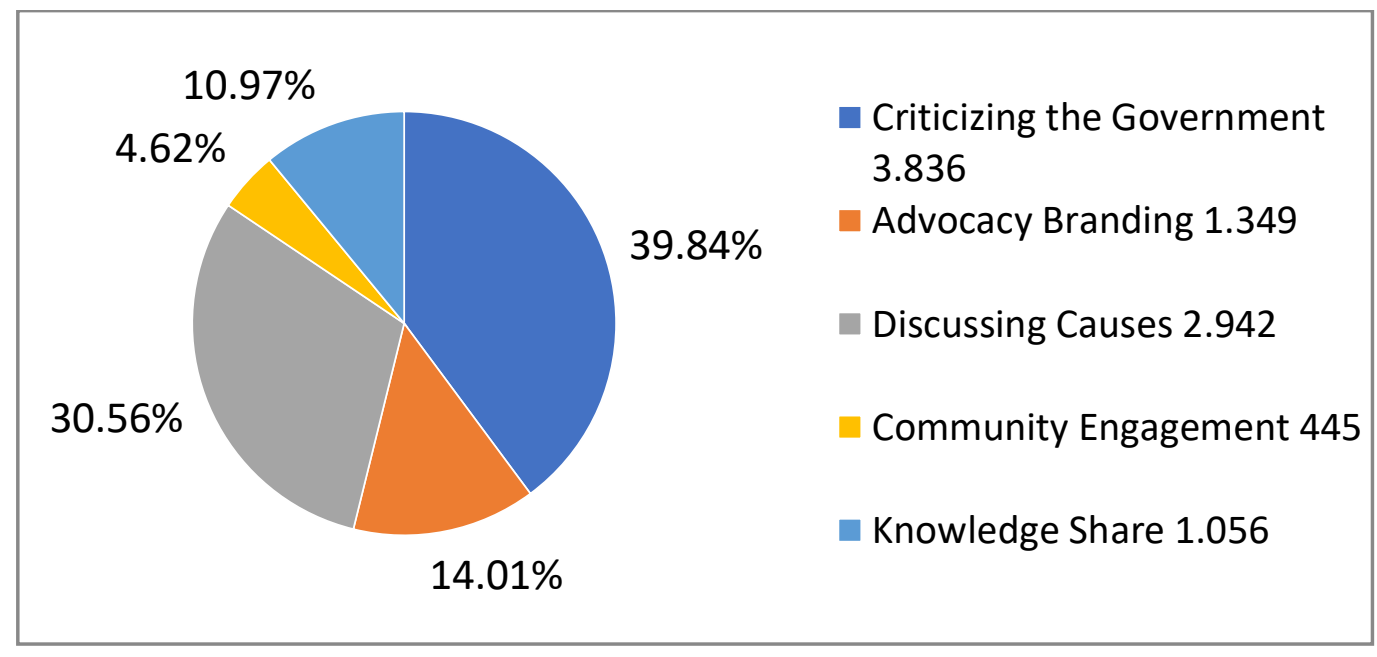

Figure 1. Type of Tweets $n$ \#SawitBaik Campaign

Furthermore, in the classification of message types, advocacy branding places the top third position where the contents of the message express branding on the activities or activities carried out related to \#SawitBaik campaign. The next category is knowledge share, which has $10.9 \%$ of the total tweets, this shows that the message given related to knowledge and information about palm oil campaign is not as much as other categories, although \#SawitBaik campaign is the main foundation for information and education to the public regarding on palm oil. The last is the community engagement category, which places the last position or equivalent to $4.62 \%$ of the total tweets. This community engagement category carries a message that defines participatory community participation in the activities carried out in \#SawitBaik campaign. By looking at the results of research and analysis in the message type category, this shows that the five message categories described by Saxton et al., (2019) were found in this study. 


\subsection{Social Network Analysis Structure}

In this section, we analyze how the network can be constructed through trend analysis according to the account who has the most influence in \#SawitBaik campaign based on followers, likes, retweets, and posts on Twitter. The listing results show 10 users with various kind of background who has the most significant influence on the \#SawitBaik. The account below affects the construction of the social network formed in \#SawitBaik campaign on Twitter from the large distribution of tweets post, and also from likes and retweets on each post. The actor who has the most influence on \#SawitBaik campaign on Twitter has a variety of backgrounds such as Individual, for example, the "ernestprakasa" which has the highest influence on \#SawitBaik campaign in Twitter, NGOs such as "greenpeaceid" to Governmental Institution "sawitbaikid." The number of followers also affects the network shared of tweets to other accounts. The linkage between 10 influential actors of \#SawitBaik advocacy to the network structure is the amount of engagement with other actors that can be calculated through the centrality network.

Table 3. Influential Users in the \#SawitBaik Campaign

\begin{tabular}{llrrrr}
\hline No. & \multicolumn{1}{c}{ User } & Tweet & \multicolumn{1}{c}{ Followers } & \multicolumn{1}{c}{ Like } & \multicolumn{1}{c}{ Retweet } \\
\hline 1. & @ernestprakasa & 1 & 681,173 & 3,263 & 2,077 \\
2. & @tweetspiring & 4 & 3,007 & 1,200 & 1,800 \\
3. & @trendingtopiq & 4 & 12,700 & 717 & 1,010 \\
4. & @greenpeaceid & 1 & 934,907 & 600 & 915 \\
5. & @elisa_jkt & 3 & 33,500 & 1,099 & 830 \\
6. & @lalualfani_ & 1 & 120 & 532 & 721 \\
\hline 7. & @sawitbaikid & 96 & 533 & 279 & 781 \\
8. & @dandhy_laksono & 3 & 118,500 & 897 & 630 \\
9. & @okapi_blue & 1 & 10 & 459 & 703 \\
10. & @lini_zq & 1 & 10,600 & 573 & 594 \\
\hline
\end{tabular}

The extent of the spread and also the magnitude of the influence of one account to another account can be proven through the results of our analysis of the centrality network that involves three network components, based on degree, betweenness, and closeness centrality of the actor which can be seen in Table 5 below. Central network measurement is one form of calculation in SNA to see the opinion leader position of a topic (Freeman 1979; Liu et al., 2010) with the discussion we took is \#SawitBaik. The linkage between 10 influential actors of \#SawitBaik campaign to the network structure is the amount of engagement with other actors that can be calculated through the centrality network. The greater the number in each category, the greater the spread of other connections for the three central network measurements. As reported by Liu et al., (2010), persons with a high 
degree of centrality are more likely to become opinion leaders. The five accounts listed below are opinion leaders from \#SawitBaik campaign.

The formation of a set of ties of the network to nodes can be seen from the total value of betweenness centrality. Measurement of the number of sets of ties of the network against other actors can be done through a scale of $0-1$ on the results of betweenness centrality. The greater the numbers in betweenness centrality, the more the shape of the network formed to other actors. The last is closeness centrality, which can be interpreted as a node that measures its average farness to all other nodes. The greater the number in closeness centrality, it can be concluded that the account contributes to the spread of the network formed from one account to another. With the analysis and results of the centrality network calculation on the five most influential accounts in \#SawitBaik campaign we can conclude that the network formed in \#SawitBaik campaign is also driven by a large amount of message dissemination to one account to another account.

Table 4. Centrality Network of the Top five Influential Actors in the \#SawitBaik Campaign

\begin{tabular}{lcccc}
\hline No. & User & Degree Centrality & Betweenness Centrality & Closeness Centrality \\
\hline 1. & ernestprakasa & 0.872 & 0.533 & 0.674 \\
2. & tweetspiring & 0.621 & 0.375 & 0.316 \\
3. & trendingtopiq & 0.613 & 0.326 & 0.578 \\
4. & greenpeaceid & 0.573 & 0.284 & 0.451 \\
\hline 5. & elisa_jkt & 0.428 & 0.127 & 0.143 \\
\hline
\end{tabular}

The central network affects the number of nodes and the distribution of the network to an account and topic. This explains the form of social network construction in \#SawitBaik, which can be found in the structure of the SNA in Figure 2. As seen in the figure below, the \#SawitBaik topic, which has the greatest social network linked to the topic, is the biggest node. However, other topics emerged, such as \#Karhutla, \#SawitJahat, \#KabutAsap, \#BersamaTanggapKarhutla, which provide interesting results from our SNA construction.

Figure 2 is a structural form of social network in \#SawitBaik. The results of our SNA show that the ties of network in the network structure are formed based on the results of calculations of the degree, betweenness, and closeness level of centrality. Referring to Valente (2012), the network structure is related to a particular social outcome mechanism, which paves the way for investigating how network changes can affect outcomes. By looking at the topics that have emerged along with \#SawitBaik campaign, this shows that the advocacy response outcomes are various as which affects the perception of the campaign. This SNA describes that the role of actors is very influential in disseminating information to other accounts that form other issues in the \#SawitBaik topic.

In our findings there is also a linkage between the overall discussion of the \#SawitBaik network structure. As referred to (Borgatti \& Ofem, 2010) that network that links between nodes are linked from paths that provide a mechanism that nodes may indirectly affect others. This is also supported by the level of the number of tweets in the total \#SawitBaik campaign discussion that dominates criticism of the government, discussing causes and therefore topics such as \#Karhutla, \#SawitJahat, \#KabutAsap appear along with \#SawitBaik 
campaign. As referred to the most influential actors in \#SawitBaik campaign the social network structure above shows the size of the network on the account of a topic based on the level of engagement of actors who have a large influence. The shape of this network also shows the complexity of the role of actors in influencing a topic being discussed. In addition, Figure 2 shows that the role of actors can be different even though there is one classification.

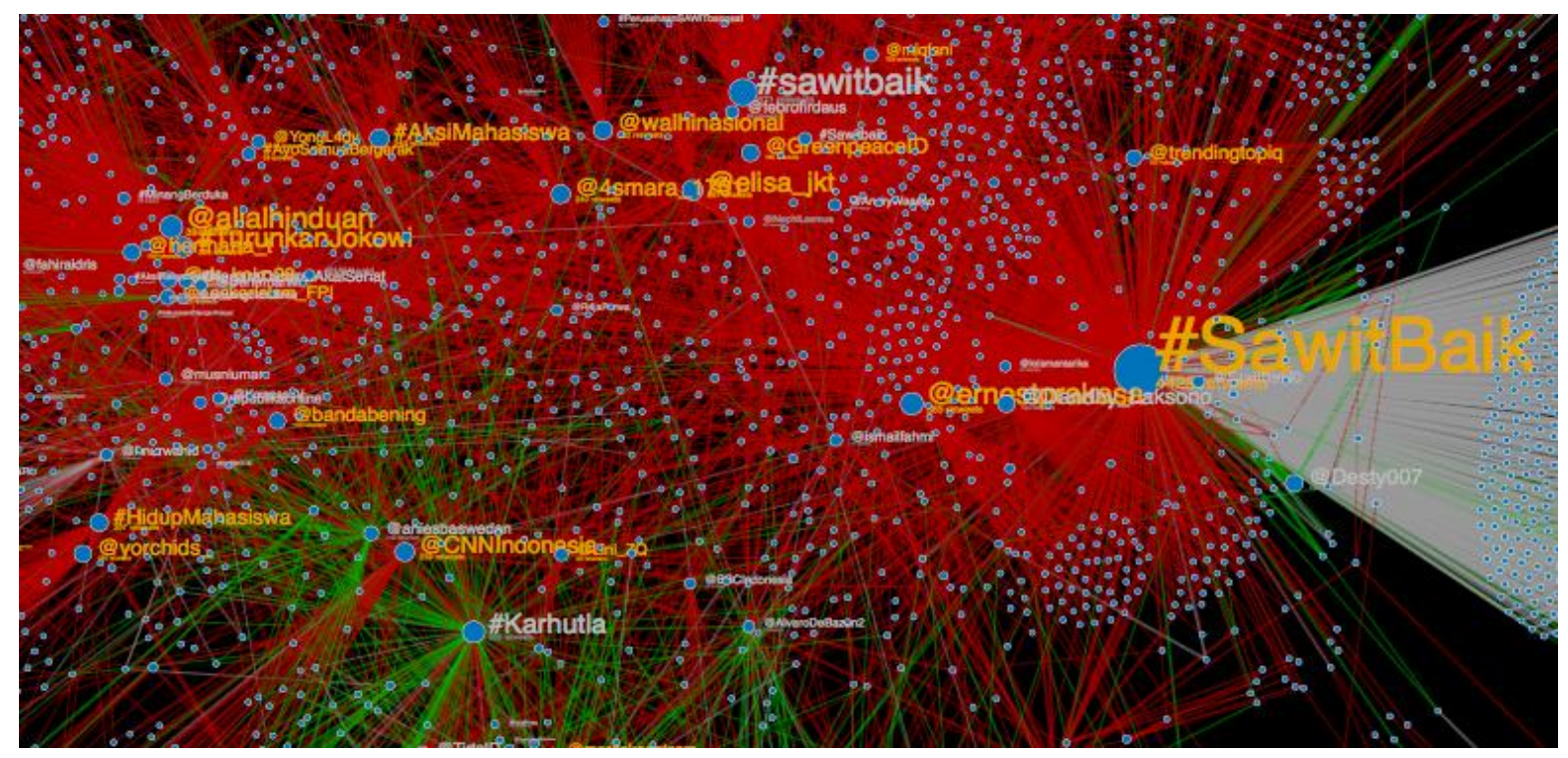

Figure 2. Social Network Analysis Structure on the \#SawitBaik Hashtag.

\section{Conclusions}

The \#SawitBaik campaign sought to generate public support for the Indonesian government's palm oil program. Based on our findings, the campaign drew criticism from the online community due to the types of messages sent. Overall, the campaign did not reflect the public interest. The government tried to influence the citizens, generate public support, and shape, and defend the legitimacy of palm oil activities. However, the \#SawitBaik digital campaign was not appealing to the public and did not succeed. Moreover, it did not serve as a bridge between government demands and public interests.

By exploring message content through trend analysis of influential actors, our study found supporting factors in how messages spread. The results reveal the formation of social network construction. In the classification of messages related to \#SawitBaik advocacy, we found facts in the community's response to this campaign, which dominated the criticism of the government. Although most of the responses from the campaign lead to campaign evaluations, there are also messages that provide educational information, community engagement, and branding about palm oil.

This study also found that the formation of social networks is influenced by influential actors who have a large engagement with other accounts. These are based on several factors, such as likes and retweets. By calculating the centrality network, we can show the position of actors as they spread messages to other actors. These findings indicate that the political marketing target for palm oil programs was not achieved. However, the \#SawitBaik 
campaign was a reliable channel for the government to communicate its vision and mission in order to persuade citizens and maintain a good public image.

The research has limitations related to the depth of analysis of social network structures. Additional measurements in SNA would require a large number of data. Our analysis indicates that some actors have a large influence in the policy campaign process and other emerging issues. The \#SawitBaik campaign was designed to generate awareness and public knowledge about the palm oil industry. Therefore, we recommend that the actors in \#SawitBaik continue to provide education and information to the public, which is aligned with their political marketing intentions.

This study has documented the actors and their involvement in the \#SawitBaik campaign through a thorough literature review. The work maps a better understanding of political marketing using social media classifications of the actors behind the \#SawitBaik digital campaign. These classifications offer critical insights depending on their positioning as either an internal or external actor in the digital campaign. In our \#SawitBaik Twitter analysis, the results suggest that actors play significant roles, which may be reflected in future digital campaigns: educating, criticizing, providing information, expanding the news, and allocating resources.

\section{Conflicts of interest}

Author declares no conflict of interest.

\section{References}

Austin, K., Mosnier, A., Pirker, J., McCallum, I., Fritz, S., \& Kasibhatla, P. (2017). Shifting patterns of oil palm driven deforestation in Indonesia and implications for zero-deforestation commitments. Land Use Policy, 69, 41-48. doi: https://doi.org/10.1016/j.landusepol.2017.08.036

Barisione, M., Michailidou, A., \& Airoldi, M. (2017). Understanding a digital movement of opinion: the case of \#RefugeesWelcome. Information, Communication \& Society, 22(8), 1145-1164. doi: https://doi.org/10.1080/1369118x.2017.1410204

Borgatti, S., \& Ofem, B. (2010). Social Network Theory and Educational Change. Lexington, KY United States: University of Kentucky

Bruns, A., \& Burgess, J., Highfield, T., Kirchhoff, L., \& Nicolai, T. (2011). Mapping the Australian networked public sphere. Social Science Computer Review, 29(3), 277-287. doi: https://doi.org/10.1177/0894439310382507

Bryson, J. M. (2004). What to do when stakeholder matter. Stakeholder identification and analysis techniques. Public Management Review, 6 (1), 21-53. doi: https://doi.org/10.1080/14719030410001675722

Burger, T. (2015). Use of digital advocacy by German nonprofit foundations on Facebook. Public Relations Review, 41(4), 523-525. doi: https://doi.org/10.1016/j.pubrev.2015.07.007

Casey, J.(2011). Understanding advocacy: A primer on the policy making role of non-profit. New York: Center for Non Profit Strategy and Management, Baruch College

Cook, T. (2010). Governing with the news. Chicago: University of Chicago Press.

Duram, L. A., \& K. G. Brown. (1999). Assessing public participation in U.S. watershed planning initiatives. Society Nat. Resources, 12,455-467. doi: https://doi.org/10.1080/089419299279533

Friedrichsen, M. (2013). Handbook of social media management. New York: Springer.

Goldkind, L., \& McNutt, J. (2019). We could be unicorns: Human services leaders Moving from Managing Programs to Managing Information Ecosystems. Human Service Organizations: 
Management, Leadership \& Governance, 43(4), 269-277. doi: https://doi.org/10.1080/23303131.2019.1669758

Hänska, M., \& Bauchowitz, S. (2018). “\#ThislsACoup: The emergence of an anti-Austerity hashtag across Europe's twittersphere" in L Basu, S Schifferes, and S Knowles (eds.) The Media and Austerity: Comparative Perspectives. London, United Kingdom: Routledge.

Happer, C., \& Philo, G. (2013). The Role of the media in the construction of public belief and social change. Journal of Social and Political Psychology, 1(1), https://doi.org/10.5964/jspp.v1i1.96

Himelboim, I., McCreery, S., \& Smith, M. (2013). Birds of a feather tweet together: Integrating network and content analyses to examine cross-ideology exposure on Twitter. Journal of computer-mediated communication, 18(2), 154-174. doi: https://doi.org/10.1111/jcc4.12001

Himelboim, I., Smith, M. A., Rainie, L., Shneiderman, B., \& Espina, C. (2017). Classifying Twitter topic-networks using social network analysis. Social media+ society, 3(1), 2056305117691545. doi: https://doi.org/10.1177/2056305117691545

Johansson, H., \& Scaramuzzino, G. (2019). The logics of digital advocacy: Between acts of political influence and presence. New Media \& Society, 21(7), 1528-1545. doi: https://doi.org/10.1177/1461444818822488

Kurt, H., \& Karaduman, S. (2012). Usage of Social Media by Political Actors: An Analysis on the Usage of Twitter by Leaders of Political Parties in Turkey. MediAnali: međunarodni znanstveni časopis za pitanja medija, novinarstva, masovnog komuniciranja i odnosa s javnostima, 6(12), 1-15.

Kavanagh, D. (1995). Election campaigning: the new marketing of politics. Oxford: Blackwell Lees-Marshment, J. (2011). The political marketing game. Basingstoke: Palgrave Macmillan.

Lewis, D. (2010). Nongovernmental organizations, definition and history. International encyclopedia of civil society, 1056-1062.

Liu, W., Sidhu, A., Beacom, A., \& Valente, T. (2017). Social Network Theory. The International Encyclopedia of Media Effects, 1-12.

Lock, A. \& Harris, P. (1996). "Political marketing - vive la différence!", European Journal of Marketing, 30(10/11), pp. 14-24. https://doi.org/10.1108/03090569610149764

Maarek, P. J. (1995). Political marketing and communication. London: John Libbey

Marian, C. (2013). Communication and Political Marketing. Res. \& Sci. Today, 6, 44.

McNair, B. (1996). Performance in politics and the politics of performance". In L'Etang, J. and Pieczka, M. (Eds.) Critical perspectives in public relations. London: Thompson International

Negara, F. 2019. Kementerian BUMN. Retrieved 18 December 2019, from http://www.bumn.go.id/ ptpn5/berita/1-Kominfo-Ingin-Sawit-Jadi-Kekuatan-Ekonomi-Indonesia

Newman, B. (1994) The marketing of the president: Political marketing as campaign strategy. London: Sage

Robinson, M. (2006). Budget analysis and policy advocacy: the role of non-governmental public action. Working paper series, 279. Brighton: IDS.

Sabatier, P. (2007). Theories of the policy process (1st ed., pp. 21 - 45). Colorado: Westview Press.

Sandelowski, M. (2000). Focus on research methods: Whatever happened to Qualitative description? Research in Nursing \& Health, 23, 334-340. doi: https://doi.org/10.1002/1098240X(200008)23:4<334::AID-NUR9>3.0.CO;2-G

Saxton, D. I., Brown, P., Seguinot-Medina, S., Eckstein, L., Carpenter, D. O., Miller, P., \& Waghiyi, V. (2015). Environmental health and justice and the right to research: institutional review board denials of community-based chemical biomonitoring of breast milk. Environmental Health, 14(1), 90. doi: https://doi.org/10.1186/s12940-015-0076-x

Saxton, G., Niyirora, J., Guo, C., \& Waters, R. (2015). \#AdvocatingForChange: The strategic use of hashtags in social media advocacy. Advances In Social Work, 16(1), 154-169. doi: https://doi.org/ 10.18060/17952

Scott, J., \& Carrington, P. (2012). The SAGE handbook of social network analysis. London: Sage. 
Smith, G., \& French, A. (2009). The political brand: A consumer perspective. Marketing Theory, 9(2), 209-226. doi: https://doi.org/10.1177/1470593109103068

Suharso, P. (2019). Pemanfataan Drone Emprit dalam melihat trend perkembangan bacaan digital melaui akun Twitter. Anuva, 3(4), 333-346. doi: https://doi.org/10.14710/anuva.3.4.333-346

Suwarno, W. (2019). The Challenge of Indonesian Diplomacy Against Palm Oil Discrimination. Jurnal Ilmiah Hubungan Internasional, 15(2), 197-212. https://doi.org/10.26593/jihi.v15i2.3416.197-212

Thejll-Moller, S. (2013). Social media in traditional political party campaigns: is there a winning formula? European View, 12 (1), 33-39. doi: https://doi.org/10.1007/s12290-013-0242-x

Unsicker, J. (2010). Confronting power: The practice of policy advocacy. United States: Kumarian Press.

Vassiliadis, C., Andronikidis, A., Belenioti, Z. (2015). Classifying and Profiling Social Media Users: An Integrated Approach. The European Conference on Media, Communication and Film. $178-$ 182.

Wring, D. (1997). Reconciling marketing with political science: theories of political marketing. Journal of Marketing Management, 13(7), 651-663. doi: https://doi.org/10.1080/0267257X.1997.9964502

Yin, Robert K. (2009). Case Study Research: Design and Methods. Thousand Oaks, CA: Sage

Zelenak, L. A. (2013). Using Design Strategy to add Value to a Political Campaign. Canterbury, United Kingdom: Kent State University.

Zheng, Q., \& Liu, S. (2017). Crowdfunding as a practice of cultural citizenship in China: A case study of Four NGOs". Journal of Creative Communications, 12(1), 1-12. doi: https://doi.org/10.1177/0973258616688965 